\title{
A compilation of bioactive compounds from Ayurveda
}

\author{
Ramar Perumal Samy ${ }^{1}$, Peter Natesan Pushparaj ${ }^{2}$ and Ponnampalam Gopalakrishnakone ${ }^{1, *}$ \\ ${ }^{1}$ Venom and Toxin Research Programme, Department of Anatomy, Yong Loo Lin School of Medicine, National University of Singapore, \\ Singapore-117597; ${ }^{2}$ Department of Physiology, Yong Loo Lin School of Medicine, National University of Singapore, Singapore-117597; \\ Ponnampalam Gopalakrishnakone* - Email: antgopal@nus.edu.sg; Phone: 65-65163207; Fax: 65-67787643; Corresponding author
}

received August 16, 2008; accepted September 17, 2008; published November 02, 2008

\begin{abstract}
:
This review deals with the key bioactive compounds and the role of medicinal plants in Ayurvedic systems of medicine in India and their earlier investigation. There has been an increase in demand for the Phytopharmaceutical products of Ayurveda in Western countries, because of the fact that the allopathic drugs have more side effects. Many pharmaceutical companies are now concentrating on manufacturing of Ayurvĕdic Phytopharmaceutical products. Ayurvěda is the Indian traditional system of medicine, which also deals about pharmaceutical science. Different type of plant parts used for the Ayurvedic formulation; overall out line of those herbal scenario and its future prospects for the scientific evaluation of medicinal plants used by traditional healers are also discussed. In India most of them, where Ayurvedic treatment is frequently used, for their ailments and provides instructions to local people how to prepare medicine from the herbs. As much as possible importance is also given for the taxonomic literature.
\end{abstract}

Keywords: Ayurvedic system; medicinal plants; phytopharmaceutical products; allopathy; traditional healers

Background:

The Ayurvedic concept appeared and developed between 2500 and $500 \mathrm{BC}$ in India. The literal meaning of Ayurveda is "science of life," because ancient Indian system of health care focused views of man and his illness. It is pointed out that the positive health means metabolically well-balanced human beings. According to Ayurveda, the disease evolves from the body due to external factors. It has a vast literature in Sanskrit covering all aspect of diseases, pharmacy and therapeutics. The practice of Ayurveda therapeutics consisted of 8 sections divided into 180 chapters and listed 314 plants, which are used as medicines in India [1]. The Indian subcontinent is a vast repository of medicinal plants that are used in traditional medical treatments [2]. Many Westerners have long regarded the Indian systems of medicine as a rich source of knowledge [1]. In India, around 20,000 medicinal plants have been recorded [3] however traditional communities are using only 7,000 - 7,500 plants for curing different diseases [4-6]. The medicinal plants are listed in various indigenous systems such as Siddha (600), Ayurveda (700) and Amchi (600), Unani (700), Allopathy which 30 plant species for ailments [7]. Even today, majorities of the medicines are prepared from the plant and animal products, minerals and metals etc. Major pharmaceutical industries depend on the plant products for the preparation of Ayurvedic medicines. In the present context, the Ayurvedic system of medicine is widely accepted and practiced not only in the Indian Peninsula but also in the developed countries such as Europe, United States and Japan. Plant derived medicines have been the first line of defense in maintaining health and combating diseases [8-9]. In the last century, roughly 121 pharmaceutical products have been discovered based on the information obtained from the traditional healers [10].
Chemical principles from natural sources have become much simpler and have contributed significantly to the development of new drugs from medicinal plants [11-12]. Biologically active compounds from natural sources have always been of great interest to scientists working on infectious diseases. Research to find out scientific evidence for claims of plants used for Indian Ayurvedic system of medicine has been intensified. Detailed research on the chemistry and pharmacology of products of plant origin are much essential and this may eventually lead to the discovery of medicine that can be used in the treatment of several diseases [3]. Moreover, these local Ayurvedic preparations are scientifically evaluated and disseminated properly, our indigenous population can be given better access to efficacious drug treatment and improved health status [13-14] However, over commercial exploitation of these plant (herbal) products frequently degradation of natural resources are reported to be major threats to medicinal plants in India. The aim of the present review is to understand the knowledge of plants used for Ayurvedic preparations, can be extended for future scientific investigation near future.

\section{Plants in traditional medicines:}

Four thousand years ago, the medical knowledge of the Indian subcontinent was termed as Ayurveda. Ayurveda remains an important system of medicine and drug therapy in India. Plant alkaloids are the primary active ingredients of Ayurvedic drugs. Today the pharmacologically active ingredients of many Ayurvedic medicines are being identified and their usefulness in drug therapy being determined. As mentioned in the introduction only a certain percentage of plants are used in traditional medicines. It is roughly estimated that of the discovered 
17,000 species, nearly 3,000 species are used in medicinal field [15]. The therapeutic action of important medicinal plants and its parts used. The indigenous systems of medicine in India are reported in Table 1 under supplementary material. The pharmacological properties of some Ayurvedic crude drugs support for their therapeutic claims (Table 2 in supplementary material). Sărangdhara mentioned detailed information about various formulations with respect to their methods of preparation as well as basic standards and are documented in Sărangdhara Samhita.

\section{Achillea millefolium L. (Biranjasipha)}

A simulative tonic and carminative that helps expel gas from the stomach and intestines. It has a very healing and soothing effect on the mucous membranes. Aqueous extracts are used for thinning hair [1].

\section{Argyreia speciosa Sweet (Vridha daraka, Elephant creeper)}

The roots and seeds are used to support the nervous system, geriatric tonic and mild aphrodisiac. The whole plant is reported to have purifying properties. It has been given to help maintain healthy joints [1].

\section{Asparagus racemosus Wild (Shatavari, Wild asparagus)}

Shatavari is the main Ayurvedic rejuvenative for women. It is recommended for women those who had hysterectomies, as it supplies many female hormones. It also helps to maintain urinary tract and strengthens the immune system. It purifies the blood [1].

\section{Capparis spinosa L. (Himsra, Capers)}

Capers are a hepatic stimulant that has been used for improving the functional efficiency of the liver. The recent experimental work also confirms its protective action on the histological architecture of the liver and its positive effect on liver glycogen and serum proteins [1].

\section{Cichorium intybus Linn (Kasani, Wild Chicory)}

Chicory is a powerful hepatic stimulant that increases bilesecretion, promotes digestion and enhances the action of capers. Experimental evidence has been proved on its action on liver glycogen. Recent studies have shown inhibition of free radical induced DNA damage [16].

\section{Commiphora mukul Engl. (Guggul)}

Guggul is a resin, the major ingredient in joint care and immuno care that has been regarded as a remedy in Ayurvedic medicine, known to increase white blood cell count and to possess strong immuno-modulating properties. Guggul is one of the "broad spectrum" health products with a wide range of benefits. Mode of action makes this product very helpful not only in protecting against the common cold but also in various other conditions. It has been shown to have remarkable properties as an adjuvant of other types of therapies. In addition, lower cholesterol and triglycerides, while maintaining the HDL to LDL ratio has long known Guggul. It has been subjected to hundreds of clinical studies [3].

\section{Crocus sativus L. (Kumkuma, Saffron)}

Saffron contains a number of carotenoid pigments generally known for their antioxidant properties. The flower is reported to provide a natural source of two B vitamins, Riboflavin and Thiamine. It is a mild stimulant and is considered as a promoter of the immune defenses in Ayurvedic therapies [1].

Cyperus scariosus Br. (Nagarmusta, Umbrella's edge) Nagarmusta is mostly useful in supporting healthy genitourinary system. Studies are also being conducted on hepatoprotective properties [17].

Didymocarpus pedicellata (Shilapushpa)

Diuretic that has been shown to be effective in supporting a healthy urinary tract [2].

\section{Garcinia camboia Desr (Garcinia)}

Garcinia fruit extract has used as a flavor in meat and seafood cooking. The most recent studies have shown that fruits contain biologically active compounds (-) Hydroxy Citric Acid. HCA is known to inhibit the synthesis of lipids and fatty acids. HCA inhibits the enzyme ATP - Citrate lyaze that leads to reduce production of acetyl CoA, which is a key substance in fat and carbohydrate metabolism. Therefore, formation of LDL and triglycerides is very low. It also suppresses appetite by promoting synthesis of glycogen. That way the brain gets signals of fullness and satisfaction sooner. Garcinia contains significant amounts of vitamin $\mathrm{C}$ and used as a heart tonic [1].

\section{Glycyrrhiza glabra L. (Yashti-madhu, Licorice)}

Licorice is a versatile medicine in India and China, for gastrointestinal health. It is a mild laxative, which soothes and tones the mucous membranes and relieves muscle spasms. Clinical studies have proved that the Licorice extracts to be more effective as well known synthetic alternatives. It is rich in flavonoids and is currently investigated as an antioxidant, cancer protecting, botanical boosting and certain immune functions such as interferon production. Its mode of action is as an anti-mutagen, preventing damage to genetic material that can eventually result in cancer [18].

\section{Gymnema sylvestre R.Br. (Meshashringi, Gurmara)}

Gurmara, whose Sanskrit name means literally "sugar destroyer", has been shown in vitro to have a glycolytic action and reduce the strength of a glucose solution. It has been used in Ayurveda to regulate sugar metabolism for several centuries. It increases insulin production, regeneration of pancreas cells and the site of insulin production. Another property is abolishing the taste of sugar, so that Gurmara has been effective to suppress and neutralize the craving for sweets [1].

\section{Melia azadirachta L. (Persian lilac)}

Neem, one of the most famous plants found throughout India, has strong health alleviating activity. It has been used as a tonic and astringent that promotes healing. The extract has shown anti-spasmodic action. It can be used in the form of powder and liquid extract. Its usage in Ayurvedic medicine for thousands of years has proved its detoxifying properties. It has shown most beneficial effects for the circulatory, digestive, respiratory and urinary 
systems [19].

Momordica charantia L. (Karela, Bitter melon)

Karela has been widely used in Ayurvedic medicine. It contains Gurmarin, a polypeptide considered to be similar to bovine insulin and has been shown in clinical studies to achieve a strong sugar regulating effect by suppressing the neural responses to sweet taste stimuli [1].

\section{Moringa pterygosperma Gaertn (Shigru, Horseradish tree)}

Shigru contains physiologically active principles that have been shown to be effective in a broad range of health needs. For example, it contains "Pterygospermin", an antibiotic-like substance [20].

\section{Mucuna pruriens Baker (Kapikachchhu, Cow-itch plant)}

It is reported as a good natural source of L. dopa. That lends much credibility to the old claim from Ayurvedic physicians that $M$. pruriens is a very effective tonic for nervous system. Studies have demonstrated its usefulness maintaining optimum performance of the nervous system [1]

Nardostachys jatamansi DC. (Jatamansi, Musk root) Jatamansi is relaxing plant with established effectiveness for mental health. Ayurvedic practitioners include it in their formulations to address anxiety. It has been shown effective in maintain a restful sleep and with many menopausal symptoms [1].

\section{Orchis mascula L. (Salabmisri, Salep orchid)}

Nerve stimulant and revigorating tonic that has long been known for its value in cases of sexual weakness. It has also been tested recently for cases of nervous debility [2].

\section{Piper longum L. (Pippali, Indian Long Pepper)}

Pippali is a powerful stimulant for both the digestive and the respiratory systems and has showed a rejuvenating effect on lungs. It plays an important role in aiding the thermogenic response, i.e. the release of metabolic heat energy. This effect is the result of increased thyroid hormone level in the body. Pippali a typical Ayurvedic complementary component whose benefit is to increased the bioavailability and enhance absorption of the other active ingredients [19].

Piper nigrum L. (Maricha, Black pepper)

The black pepper is one of the most renowned culinary spices. It contains an alkaloid piperine that has been widely used to amplify the body's ability to absorb nutrients contained in the food and aid the digestive process [19].

\section{Rubia cordifolia L. (Manjishta, Indian Madder)}

Indian madder is considered the best Ayurvedic bloodpurifying herb. In Ayurvedic medicine, it is used as an immune regulator. Its antioxidant properties are also being investigated. Its role in supporting heart health is evidenced by studies showed that it regulates the tendency of blood to form clots regulates blood pressure and blood vessel constriction [21].

\section{Saxifraga ligulata Wall (Pasanavheda)}

ISSN 0973-2063 (online) 0973-2063 (print)

Bioinformation 3(3): 100-110 (2008)
Diuretic action with the unique property of reaping optimum urinary tract health is reported. $S$ ligulata supports bladder by acting on the crystalloid-colloid balance and keeping calcium salts in solution [1].

Solanum nigrum L. (Kakamachi, Black Nightshade) Kakamachi plant and berries contains various alkaloids that have been isolated and shown to have a dilatation action on the pupil. This is mainly used for healthy liver, skin, kidneys and bladder. Recent studies indicate that the hepatoprotective effects of the crude extract may be due to the suppression of the oxidative degradation of DNA [22].

\section{Terminalia arjuna W. and A. (Arjuna)}

Arjuna is a heart tonic that has been used to support the cardiovascular functions since ancient times with known cardioprotective effects. Recent work has investigated the mechanism of this activity and has shown a dosedependent regulation of blood pressure and heart rate. There was also a slight increase in the HDL-to-total cholesterol ratio and an overall improvement in the cardiovascular profile [23-24].

Terminalia chebula Retz. (Haritaki, Chebulic myrobalam)

In Sanskrit, Haritaki means "carries away" (all diseases). Haritaki is a safe and effective purgative, expectorant and tonic. It is a component of the classic Ayurvedic combination called "Triphala" (three fruits). Tiphalpha is an important Ayurvedic medicine, which often promotes health through successive steps of purification and detoxification. It is known to have strong anti-mutagenic activity, because of its very rich content vitamin C [1].

\section{Tinospora cordifolia Miers (Guduchi)}

Guduchi is a rich source of natural vitamin $\mathrm{C}$ that has now been proved to be effective in inhibiting the growth of bacteria and in building up the immune resistance. Research is now providing clues to Guduchi's immuneboosting ability. In a scientific investigation using human white blood cells, it increased the killing ability of macrophages, the immune cells responsible for fighting invaders [19].

\section{Tribulus terrestris L. (Gokshura, Small caltrops)}

Gokshura is a mild diuretic widely used to promote the flow of urine, cools and soothes the membranes of the urinary tract and inhibits the production of oxalate, a substance that cause microcrystals. Gokshura's role in maintaining a healthy heart has also been proved. It contains saponins that may improve the heart function by dilating coronary arteries, thereby boosting circulation to the heart. In China, 406 patients were treated with these saponins and their EKG improved in $67 \%$ of the cases [1].

\section{Withania somnifera (Linn.) Dunal (Ashwagandha)}

Ashwagandha is one of the best Ayurvedic herbs and holds a place in the Ayurvedic traditions similar to Ginseng in Chinese therapies. It has been often referred to as the "Indian Ginseng". It has been used for thousands of years as a popular remedy in Ayurvedic systems for many conditions. It is one of the best health tonics and restorative agents that have been used to treat general debility, 
exhaustion, stress induced fatigue and insomnia. Studies have shown its rejuvenating effect, particularly for the muscles and bone marrow. Various alkaloids and with anoloides in Withania somnifera have shown impressive results in scientific testing, two of them as stimulants for the immune system [16].

\section{Zingiber officinale Rosc (Sunthi, Ginger)}

Ginger is the delicious common spice used in Ayurvedic medicine to improve digestion and to prevent nausea.These properties for helping bowel movements and relaxing the muscles are controlling the digestive system. Ginger is considered an adjuvant in many Ayurvedic formulas in which it enhances absorption and prevents gastrointestinal side effects [19].

\section{Medicinal plants frequently used in Ayurvedic formulation}

Ayurveda, whose history goes back to $5000 \mathrm{BC}$., is one of the ancient health care systems. The Ayurveda was developed through daily life experiences with the mutual relationship between mankind and nature. The ancient text of Ayurveda reports more than 2000 plant species for their therapeutic potentials. Besides Ayurveda, other traditional and folklore systems of health care were developed in the different time periods in Indian subcontinent, where more than 7500 plant species were used. According to a WHO estimate, about $80 \%$ of the world population relies on traditional systems of medicines for primary health care, where plants form the dominant component over other natural resources [25]. Ayurvěda, pañcavidhakaşăyakalpana are the two basic pharmaceutical preparations, from which all the other preparations are formulated. Sărangdhara mentioned detailed information about various formulations with respect to their methods of preparation as well as basic standards and are documented in Sărangdhara Samhita [26]. The different drug is prepared by percentage dry weight of the plant parts for the Ayurvedic formulations.

\section{Anemia:}

Asparagus racemosus (roots) $20 \%$, Withania somnifera (roots) $20 \%$, Phyllanthus emblica (fruits) $15 \%$, P. amarus (leaves) $10 \%$, Tephrosia purpurea (leaves) $10 \%$, Plumbago zeylanica (roots) 5\%, Glycyrrhiza glabra (roots) $15 \%$ and Piper longum (fruits) $5 \% .4 \mathrm{gm}$ of powder is given to the patient, twice daily with water.

\section{Asthma bronchitis:}

Solanum xanthocarpum (whole plant) 25\%, Piper longum (fruits) $10 \%$, Adhatoda vasica (leaves) $25 \%$, Zingiber officinale (roots) 10\%, Curcuma zedoaria (roots) $10 \%$, Ocimum sanctum (leaves) $10 \%$ and Phyllanthus emblica (fruits) 10\%. $4 \mathrm{gm}$ (one teaspoonful) of mixed powder should be given to the patient, twice a day (morning and at bedtime) with water [27].

\section{Arthritis:}

Piper longum (fruits) $10 \%$, S. xanthocarpum (whole plant) $15 \%$, Withania somnifera (roots) $10 \%$, Terminalia chebula (fruits) $10 \%, T$. bellerica (fruits) $10 \%$, Curcuma zedoaria (roots) $15 \%$, Phyllanthus emblica (fruits) $15 \%$ and Ricinus communis (roots) $15 \%$. 4 gm of mixed powder should be given to the patient, twice daily (morning and evening, one hour before meals) with ginger juice for rheumatic problems [27].

\section{Blood circulation:}

Zingiber officinale (roots) 20\%, Piper longum (roots) $10 \%$, Withania somnifera (roots) $10 \%$, Phyllanthus emblica (fruits) 10\%, Curcuma longa (roots) $10 \%$, Terminalia bellerica (fruits) $10 \%, T$. chebula (fruits) $10 \%$, Ocimum sanctum (leaves) $10 \%$ and Tephrosia purpurea (leaves) $10 \%$. $4 \mathrm{gm}$ of powdered mixer is given to the patient, twice daily with water [27].

\section{Chronic constipation:}

Holarrhena antidysenterica (bark) 10\%, Plumbago ovata (husk) $20 \%$, Terminalia bellerica (fruits) $10 \%$, T. chebula (fruits) 15\%, Phyllanthus emblica (fruits) 15\%, Cassia angustifolia (leaves) $20 \%$ and Glycyrrhiza glabra (roots) $10 \% .4 \mathrm{gm}$ of powdered mixer is given to the patient, at night before going to bed, with water [27].

\section{Cancer:}

Azadirachta indica (bark) 20\%, Bauhinia variegata (bark) $15 \%$, Crataeva nurvala (bark) 15\%, Terminalia chebula (fruits) $15 \%, T$. bellerica (fruits) $10 \%$, Holarrhena antidysenterica (bark) $10 \%$ and Tinospora cordifolia (stems) $15 \% .4 \mathrm{gm}$ of mixed powder should be given to the patient, twice a day (morning and night) with lukewarm honey for cancer cure [27].

\section{Chronic fever:}

Tinospora cordifolia (stems) 15\%, Ocimum sanctum (leaves) $15 \%$, Adhatoda vasica (leaves) $15 \%$, Azadirachta indica (leaves) 15\%, Holarrhena antidysenterica (bark) $10 \%$, Piper longum (fruits) $10 \%$, Zingiber officinale (roots) $10 \%$ and Terminalia bellerica (fruits) $10 \% .4 \mathrm{gm}$ of mixed powder is given to the patient, twice daily before meals with water [27].

Cough:

Phyllanthus emblica (fruits) $25 \%$, Adhatoda vasica (leaves) $20 \%$, Ocimum sanctum (leaves) $10 \%$, Piper longum (fruits) $10 \%$, Zingiber officinale (roots) $10 \%$, Glycyrrhiza glabra (roots) $15 \%$ and Solanum xanthocarpum (whole plant) 10\%. 3 gm of mixed powder should be given to the patient twice daily (morning and at night before going to bed) with lukewarm mixed with honey to cure cold [27].

Cysts:

Terminalia chebula (fruits) 20\%, Azadirachta indica (bark) $20 \%$, Holarrhena antidysenterica (bark) 10\%, Terminalia bellerica (fruits) $10 \%$, Withania somnifera (roots) $20 \%$ and Tinospora cordifolia (stems) 20\%. 4 gm of mixed (one teaspoonful) powder is given to the patient, twice a day (morning and evening) with water [27].

\section{Dental diseases:}

Azadirachta indica (leaves) 15\%, A..arabia (bark) 15\%, Areca catechu (bark) 15\%, Achyranthus aspera (leaves) $10 \%$, Ficus benghalensis (bark) $15 \%$, Quercus infectoria (fruits) $15 \%$ and Symlocos racemosa (bark) $15 \%$. The powder is applied to the gums and teeth, two times a day. 


\section{Additionally a gargle of the decoction (3 gm of powder} mixed in $150 \mathrm{ml}$ of water) [27].

\section{Diarrhoea:}

Holarrhena antidysenterica (bark) 25\%, Aegle marmelos (fruits) $25 \%$, Zingiber officinale (roots) $10 \%$, Terminalia chebula (fruits) $10 \%$, Cyperus rotundus (roots) $10 \%$, Syzygium cumini (seeds) $10 \%$ and Phyllanthus emblica (fruits) $10 \% .3 \mathrm{gm}$ of mixed powder is given to the patient, three times a day, with curd for dysentery and diarrhoea [27].

\section{Dislocation of bones:}

Asparagus racemosus (roots) $15 \%$, Withania somnifera (roots) 15\%, Azadirachta arabica (bark) 20\%, Terminalia arjuna (bark) $20 \%, T$. chebula (fruits) $10 \%, T$. bellerica (fruits) $10 \%$ and Phyllanthus emblica (fruits) $10 \% .3$ gm of powdered mixer is given to the patient, twice a day with water for dislocation of bones and fractures [27].

\section{Diabetes:}

Gymnema sylvestre (leaves) 30\%, Tinospora cordifolia (stems) $15 \%$, Azadirachta indica (leaves) $10 \%$, Phyllanthus emblica (fruits) $20 \%$, Curcuma longa (roots) $10 \%$ and Aegle marmelos (leaves) $15 \%$. 4 gm of mixed powder should be given to the patient, twice a day with water [27].

\section{Fistula:}

Glycyrrhiza glabra (roots) 20\%, Terminalia chebula (fruits) $20 \%$, T. bellerica (fruits) $15 \%$, Tinospora cordifolia (stems) 15\%, Azadiracta indica (leaves) $15 \%$, and Withania somnifera (roots) 15\%. 3 gm of mixed powder should be given to the patient, twice daily with water to treat fistula [27].

\section{Female sterility:}

Asparagus racemosus (roots) $20 \%$, Withania somnifera (roots) $20 \%$, Glycyrrhiza glabra (roots) 20\%, Phyllanthus emblica (fruits) $10 \%$, Ficus glomerata (bark) $10 \%$ and F. religiosa (bark) $10 \%$. $3 \mathrm{gm}$ of powdered mixer is given to the patient twice daily, half an hour before meals with milk.

\section{General health tonic:}

Withania somnifera (roots) 20\%, Asparagus racemosus (roots) $10 \%$, Glycyrrhiza glabra (roots) $10 \%$, Tribulus terrestris (fruits) $10 \%$, Phyllanthus emblica (fruits) $15 \%$, Terminalai arjuna (bark) $15 \%$ and Centella asiatica (leaves) $10 \%$. $4 \mathrm{gm}$ of powder is given to the patient, twice daily (morning and evening) with milk [27].

\section{Gastritis:}

Zingiber officinale (roots) 10\%, Piper longum (fruits) $10 \%$, Mentha piperata (leaves) 10\%, Terminalia chebula (fruits) $15 \%$, T. bellerica (fruits) 15\%, Phyllanthus emblica (fruits) $15 \%$, Plumbago zeylanica (roots) $10 \%$ and Tinospora cordifolia (stems) 15\%. $4 \mathrm{gm}$ of (one teaspoonful) powdered mixer is given to the patient twice daily, half an hour before meals with water [27].

\section{Hair problems:}

Eclipta alba (leaves) 15\%, Centella asiatica (leaves) 15\%, Terminalia chebula (fruits) $10 \%$, T. bellerica (fruits) $10 \%$, Phyllanthus emblica (fruits) $15 \%$, Glycyrrhiza glabra (roots) $15 \%$, Tinospora cordifolia (stems) $10 \%$ and Tribulus terrestris (fruits) 10\%. 4 gm of mixed powder is given to the patient, twice a daily with honey [27].

\section{High blood pressure:}

Terminalia arjuna (bark) 35\%, T. chebula (fruits) $15 \%$, Asparagus racemosus (roots) 15\%, Zingiber officinale (roots) $10 \%$ and Withania somnifera (roots) $25 \% .4 \mathrm{gm}$ of powder is given to the patient, twice a day (morning and night) with honey [28].

\section{Heart tonic:}

Withania somnifera (roots) 10\%, Terminalia arjuna (bark) $30 \%$, T. bellerica (fruits) $10 \%$, T. chebula (fruits) $10 \%$, Cyperus rotundus (roots) 10\%, Phyllanthus emblica (fruits) $10 \%$ and Ocimum sanctum (leaves) $10 \%$. $3 \mathrm{gm}$ of powdered mixer is given to the patient, twice a day with water [27].

\section{Intestinal worms}

Holarrhena antidysenterica (bark) 10\%, Mentha piperata (leaves) $10 \%$, Tinospora cordifolia (stems) $20 \%$, Butea monosperma (seeds) 20\%, Azadirachta indica (leaves) $10 \%$, Pyllanthus emblica (fruits) $20 \%$ and Tribulus terrestris (fruits) $10 \% .3 \mathrm{gm}$ of mixed powder is given to the patient, twice daily (morning and night) with water [27].

\section{Epilepsy:}

Centella asiatica (leaves) 30\%, Withania somnifera (roots) $20 \%$, Tribulus terrestris (fruits) 15\%, Piper longum (roots) $10 \%$, Acyranthus aspera (leaves) $15 \%$ and Plumbago zeylanica (roots) $10 \%$. 3 gm mixed powder is given to the patient, twice daily (morning \& evening) with fruit juice to treat Hysteria [27].

\section{Leucorrhoea:}

Symplocos racemosa (bark) 35\%, Asparagus racemosus (roots) $15 \%$, Adhatoda vasica (leaves) $10 \%$, Aegle marmelos (fruits) $10 \%$, Phyllanthus emblica (fruits) $10 \%$ and Azadirachta indica (bark) $10 \% .3 \mathrm{gm}$ of mixed powder is given to the patient, twice daily with water [27].

\section{Leucoderma}

Psoralea cordifolia (seeds) $20 \%$, Terrmins chebula (fruits) $10 \%$, Phyllanthus emblica (fruits) $20 \%$, Azadirachta indica (bark) 20\%, Areca catechu (bark) 10\%, Tinospora cordifolia (stems) 10\% and Eclipta alba (leaves) 10\%. 3 gm of mixed powder should be given to the patient, twice a day before meals with water [27].

\section{Liver tonic}

Holarrhena antidysenterica (bark) 10\%, Eclipta alba (leaves) 20\%, Tephrosia purpurea (leaves) 20\%, Tinospora cordifolia (stems) 10\% Azadirachta indica (bark) 10\%, Phyllanthus amarus (whole plant) $20 \%$ and Plumbago zeylanica (roots) $10 \%$. $4 \mathrm{gm}$ of powdered mixer is given to the patient twice daily, half an hour before meals with water [27]. 


\begin{abstract}
Lack of appetite:
Zinziber officinale (roots) 10\%, Piper longum (fruits) $10 \%$, Pyllanthus emblica (fruits) $30 \%$, Terminalia chebula (fruits) 15\%, Tinospora cordifolia (stems) 15\%, Cassia angustifolia (leaves) $10 \%$ and Mentha piperata (leaves) $10 \%$. $4 \mathrm{gm}$ of mixed powder is given to the patient, two times a day after meals with water for indigestion [27].
\end{abstract}

\section{Male sterility:}

Withania somnifera (roots) 15\%, Mucuna pruriens (seeds) $25 \%$, Tribulus terrestris (fruits) $20 \%$, Glycyrrhiza glabra (roots) $10 \%$, Terminalia arjuna (bark) 10\%, Phyllanthus emblica (fruits) $10 \%$, Zingiber officinale (roots) $5 \%$ and Piper longum (fruits) $5 \% .4 \mathrm{gm}$ of powdered mixer is given to the patient, twice a day with honey [27].

\section{Migraine:}

Curcuma longa (roots) 15\%, Glycyrrhiza glabra (roots) $15 \%$, Azadirachta indica (bark) $15 \%$, Tinosporacordifolia (stems) $15 \%$, Terminalia chebula (fruits) $10 \%$, Ocimum sanctum (leaves) $15 \%$ and Eclipta alba (leaves) 15\%. 4 gm of mixed powder is given to the patient, twice a day with honey [27].

\section{Obesity:}

Terminalia chebula (fruits) $15 \%$, Terminalia bellerica (fruits) $15 \%$, Phyllanthus emblica (fruits) $10 \%$, Crateva nurvala (bark) $25 \%$, Tribulus terrestris (fruits) $25 \%$ and Zingiber officinale (roots) $10 \%$. 4 gm of powder is given to the patient, twice a day with warm water.

\section{Paralysis:}

Curcuma zedoaria (roots) 20\%, Withania somnifera (roots) $20 \%$, Tribulus terrestris (fruits) 20\%, Zingiber officinale (roots) $20 \%$, Piper longum (fruits) $5 \%$, Crataeva nurvala (leaves) $10 \%$ and Plumbago zeylanica (roots) $5 \% .3 \mathrm{gm}$ of powdered mixer is given to the patient, three times a day with honey [27].

\section{Prostate enlargement:}

Tinospora cordifolia (stems) 15\%, Tribulus terrestris (fruits) $15 \%$, Phyllanthus emblica (fruits) $15 \%$, Zingiber officinale (roots) $10 \%$, Butea monosperma (seeds) $10 \%$, Adhatoda vasica (leaves) 5\%, Terminalia chebula (fruits) $10 \%$, T. bellerica (fruits) $10 \%$ and Glycyrrhiza glabra (roots) $10 \%$. $4 \mathrm{gm}$ of powdered mixer is given to the patient twice a day, morning and evening before meals with water [27].

Piles:

Eclipta alba (leaves) $35 \%$, Terminalia chebula (fruits) $15 \%$, Terminalia bellerica (fruits) 10\%, Phyllanthus emblica (fruits) 10\%, Adhatoda vasica (leaves) 10\%, Plumbago zeylanica (roots) 5\%, Piper longum (fruits) 5\% and Aegle marmelos (fruits) $10 \% .4$ gm of mixed powder is given to the patient, twice daily (morning and at bedtime) with water [27].

\section{Sleeplessness:}

Withania somnifera (roots) $20 \%$, Centella asiatica (leaves) $30 \%$, Piper longum (roots) $20 \%$, Glycyrrhiza glabra (roots) $10 \%$ and Terminalia bellerica (fruits) $10 \% .3 \mathrm{gm}$

ISSN 0973-2063 (online) 0973-2063 (print)

Bioinformation 3(3): 100-110 (2008) mixed powder is given to the patient, at night before going to bed, with milk [27].

\section{Skin diseases:}

Cyperus rotundus (roots) 10\%, Tinospora cordifolia (stems) 20\%, Azadiracta indica (bark) 20\%, Terminalia chebula (fruits) $10 \%$, T. bellerica (fruits) $10 \%$, Curcuma longa (roots) $10 \%$, Phyllanthus emblica (fruits) $10 \%$ and Centella asiatica (leaves) $10 \% .3 \mathrm{gm}$ of powder is given to the patient, twice a day before meals with water to cure allergy problems [27].

\section{Sexual debility:}

Withania somnifera (roots) 10\%, Mucuna pruriens (seeds) $20 \%$, Asparagus racemosus (roots) $10 \%$, Sida cordifolia (seeds) $10 \%$, Tribulus. terrestris (fruits) $20 \%$ and Glycyrrhiza glabra (roots) $10 \%$. About 4 gm of mixed powder should be given to the patient, twice daily (morning and at night before going to bed) with milk [27].

\section{Throat diseases:}

Glycyrrhiza glabra (roots) 30\%, Terminalia chebula (fruits) $10 \%, \quad$ T. bellerica (fruits) $10 \%$, Solanum xanthocarpum (whole plant) 20\%, Piper longum (fruits) $10 \%$, Sida cordifolia (roots) $10 \%$ and Phyllanthus emblica (fruits) $10 \%$. $4 \mathrm{gm}$ of powdered mixer is given to the patient twice daily, morning and at bedtime with honey [27].

\section{Thyroid problems:}

Crataeva nurvala (bark) 20\%, Bauhinia variegata (bark) $20 \%$, Sida cordifolia (leaves) 15\%, Terminalia chebula (fruits) $10 \%$, T. bellerica (fruits) $10 \%$, Glycyrrhiza glabra (roots) $15 \%$ and Zingiber officinale (roots) 10\%. 3 gm of powdered mixer is given to the patient, twice daily with lukewarm water [27].

\section{Urinary tract:}

Tribulus terrestris (fruits) 25\%, Zingiber officinale (roots) $10 \%$, Solanum xanthocarpum (whole plant) $10 \%$, Crataeva nurvala (bark) 25\%, Tinospora cordifolia (stems) 10\%, Asparagus racemosus (roots) $10 \%$ and Tephrosia purpurea (leaves) $10 \%$. $4 \mathrm{gm}$ of powdered mixer is given to the patient, twice a day with water [27].

\section{Market potential of herbal medicines}

Herbal medicines continue to be a major market in U.S. pharmaceuticals and constitute a multi-billion dollar business. Approximately 1500 botanicals are sold as dietary supplements; formulations are not subject to Food and Drug Administration (FDA) clinical toxicity testing to assure their safety and efficacy. The Indian herbal drug market size is about $\$ 1$ billion and the export of plant based crude drug is around $\$ 100$ million. The current market potential of herbal medicine is estimated about $\$$ 80-250 billion in Europe and USA [16]. The current market size of the herbs and natural health products in China is about USD 650 million, of which imported herbal medicines account for USD 15 million. In response to the expected improvement in modern herbal medicine and reflective of their growing demand for natural medicines, $73 \%$ of the respondents to a consumer survey indicated they would depend more on herbal medicine in the future. 


\section{Bioinformation}

Imports of herbs into Hong Kong in 2003 amounted to USD 166.4 million, a $6.8 \%$ decrease over the 2002 's imports. This reflects less imports of licorice roots of USD $0.2(-23.8 \%)$ and ginseng root of USD $123.2(-8.8 \%)$. We have listed the important medicinal plants which are exported from India are shown in table 3 (supplementary material).

\section{Conclusion:}

The traditional knowledge with its holistic and systems approach supported by experimental base can serve as an innovative and powerful discovery engine for newer, safer and affordable medicines. These plant species mentioned in the ancient texts of Ayurvedic and other Indian systems of medicines may be explored with the modern scientific approaches for better leads in the health care. Hence, the present review is focused an overall out line of plant used in Ayurvedic drug scenario and its future prospects for the further scientific investigation. Considerable research on pharmacognosy, chemistry, pharmacology and clinical therapeutics has been carried out on Ayurvedic medicinal plants. Several preclinical and clinical studies have examined cytoprotective, immunomodulatory and immunoadjuvant potential of Ayurvedic medicines. The development of these traditional systems of medicines with the perspectives of safety, efficacy and quality will help not only to preserve this traditional heritage but also to rationalize the use of natural products in the health care. Thus, we can easily identify rare and extinct plants for the conservation and preserved the traditional heritage of the traditional practitioners.

\section{References:}

[01] V. Subhose et al., Bull Indian Inst Hist Med Hyderbad., 35: 83 (2005)

[02] B. Ballabh and O. P. Chaurasia, J Ethnopharmacol., 112: 341 (2007)

[03] S. Dev, Current Sci. 73: 909 (1997).

[04] R. Perumal Samy and S. Ignacimuthu, $J$. Ethnopharmacol., 62: 173 (1998)
[05] R. Perumal Samy and S. Ignacimuthu, J. Ethnopharmacol., 69: 63 (2000)

[06] V. P. Kamboj, Current Sci., 78: 35 (2000)

[07] Rabe and J. V. Staden. J. Ethnopharmacol., 56: 81 (1997)

[08] D. John, Int. J. Crude Drug Res., 22: 17 (1984)

[09] D. J. H. Veale et al., J. Ethnopharmacol., 36: 185 (1992)

[10] C. Anesini and C. Perez, J. Ethnopharmacol., 39: 119 (1993)

[11] P. A. Cox, Ciba Foundation Symposium 154, Chichester, John Wiley \& Sons, 40 (1990)

[12] P. Cox, M. Balick. Sci American., 82 (1994)

[13] N. P. Manandhar et al., Lepr. Rev., 56: 265 (1985)

[14] N. P. Manandhar, Int. J. Crude Drug Res., 25: 236 (1987)

[15] M. P. Nayar, Bull. Bot. Surv.Ind., 29: 319 (1987)

[16] S. N. El and S. Karakava, Int J Food Sci Nutr., 55: 67 (2004)

[17] M. O. M. Tanira et al., J. Ethnopharmacol., 41: 201 (1994)

[18] R. A. Isbrucker and G. A. Burdock, Regulatory Toxicol. Pharmacol., 46: 167 (2006)

[19] S. Nair et al., Ind Heart Journal, 48 : 545 (1996)

[20] N. Balasinor et al., J. Ethnopharmacol., 109: 406 (2007)

[21] A. Caceres et al., J. J. Ethnopharmacol., 33: 213 (1991)

[22] J. Vlietinck et al., J. Ethnopharmacol., 46: 31 (1995)

[23] D. E. Dimayuga and S. K. Carcia, J. Ethnopharmacol., 31: 181 (1991)

[24] B.Vaidya, J. Assoc. Physicians of Ind., 42: 281 (1994)

[25] A. Ram et al., J. Ethnopharmacol., 55: 165 (1997)

[26] P. K. Mukherjee and A. Wahile, $J$ Ethnopharmacol., 103:25 (2006)

[27] A. Narayana and V. Subhose, Bull Indian Inst Hist Med Hyderabad, 35: 21 (2005)

[28] S. Govindan et al., J Ethnopharmacol., 66: 205 (1999)

Edited by $P$. Kangueane

Citation: Perumal Samy et al., Bioinformation 3(3): 100-110 (2008)

License statement: This is an open-access article, which permits unrestricted use, distribution, and reproduction in any medium, for non-commercial purposes, provided the original author and source are credited. 


\section{Supplementary material}

\begin{tabular}{|c|c|c|}
\hline Botanical names & Parts used & Therapeutic actions \\
\hline Acorus calamus L. Araceae (Vacha) & Root & $\begin{array}{l}\text { Memory loss, anxiety, bronchitis, mental fatigue sinusitis, } \\
\text { tension, headache and joint pains }\end{array}$ \\
\hline $\begin{array}{l}\text { Adhatoda vasica Nees Acanthaceae } \\
\text { (Vasaka) }\end{array}$ & $\begin{array}{l}\text { Roots and } \\
\text { leaves }\end{array}$ & $\begin{array}{l}\text { Expectorant used in asthma, bronchitis, cough and } \\
\text { dysmenorrhea. }\end{array}$ \\
\hline Aegle marmelos Corr. Rutaceae (Bilwa) & Fruit & Diarrhea, gastritis and adult onset diabetes \\
\hline $\begin{array}{l}\text { Andrographis paniculata Wallich ex Nees. } \\
\text { Acanthaceae (Kirta) }\end{array}$ & Leaves & $\begin{array}{l}\text { Children's bowel complaints, gastric acidity, viral } \\
\text { hepatitis, liver congestion and flatulence }\end{array}$ \\
\hline $\begin{array}{l}\text { Asparagus racemosus Willd. Liliaceae } \\
\text { (Shatavari) }\end{array}$ & Root & $\begin{array}{l}\text { Increases muscle strength, stomach, lungs, and sexual } \\
\text { organs, increases breast milk secretion during lactation } \\
\text { and male impotence. }\end{array}$ \\
\hline $\begin{array}{l}\text { Bacopa monnieri (L.) Penn. } \\
\text { Scrophulariaceae (Brahmi) }\end{array}$ & Leaves & $\begin{array}{l}\text { Nervous exhaustion, generalized fatigue, epilepsy, } \\
\text { improves memory, anti-ageing and bronchitis, coughs. }\end{array}$ \\
\hline $\begin{array}{l}\text { Boerhaavia diffusa L. Nyctaginaceae } \\
\text { (Punarnava) }\end{array}$ & Root & $\begin{array}{l}\text { Diuretic, laxative, expectorant used in asthma, bronchitis, } \\
\text { anemia and anti-inflammatory. }\end{array}$ \\
\hline Cedrus deodara Roxb. Coniferae (Devadaru) & Wood & $\begin{array}{l}\text { Flatulence, diarrhoea, hemorrhoids, fever, reduces and } \\
\text { promotes sweating. }\end{array}$ \\
\hline $\begin{array}{l}\text { Centella asiatica Urbann Umbelliferae } \\
\text { (Mandukaparni) }\end{array}$ & Whole plant & $\begin{array}{l}\text { Anxiety, to promote memory power and also to reduce } \\
\text { blood pressure. }\end{array}$ \\
\hline $\begin{array}{l}\text { Cinnamomum iners Reinw. Lauraceae } \\
\text { (Tejpatra) }\end{array}$ & Leaves & Used for scorpion sting. \\
\hline Datura metel L. Solanaceae (Datura) & Whole plant & $\begin{array}{l}\text { Whooping cough, muscle spasm, sciatica, asthma and } \\
\text { painful menstruation. }\end{array}$ \\
\hline Eclipta alba Hassk. Asteraceae (Bhringaraj) & Whole plant & $\begin{array}{l}\text { Liver disorders, skin and hair care, improves complexion, } \\
\text { viral hepatitis, calms the mind, memory disorders, and } \\
\text { strengthens spleen and general tonic. }\end{array}$ \\
\hline Embelia ribes Burm. Myrsinaceae (Vidanga) & $\begin{array}{l}\text { Powdered } \\
\text { berries }\end{array}$ & $\begin{array}{l}\text { Intestinal worms, skin-fungal infections, obesity, sore } \\
\text { throat and digestive strengthener. Keep the intestines free } \\
\text { of toxins. It is reported as a reducing agent of sperm count. }\end{array}$ \\
\hline $\begin{array}{l}\text { Emblica officinalis Gaertn. Euphorbiaceae } \\
\text { (Amalaki) }\end{array}$ & Fruit & $\begin{array}{l}\text { Increases red blood cell counts and therefore improves } \\
\text { anemia, asthma, bronchitis, stomach problems and } \\
\text { hemorrhoids. }\end{array}$ \\
\hline $\begin{array}{l}\text { Evolvulus alsinoides L. Convolvulaceae } \\
\text { (Shankhpushpi) }\end{array}$ & Whole plant & General weakness, nervous exhaustion and memory loss. \\
\hline $\begin{array}{l}\text { Gloriosa superba L. Liliaceae } \\
\text { (Kalapaikilangu) }\end{array}$ & $\begin{array}{l}\text { Tuber and } \\
\text { seed }\end{array}$ & $\begin{array}{l}\text { Deadly toxic to human beings, used as server ulcer in an } \\
\text { optimum dose and cure cancer. }\end{array}$ \\
\hline $\begin{array}{l}\text { Mucuna pruriens Baker Papilionaceae } \\
\text { (Kapikachchha) }\end{array}$ & Seed powder & $\begin{array}{l}\text { Hypercholesterolemia, general weakness, Parkinson's } \\
\text { disease and nervous disorders. }\end{array}$ \\
\hline Ocimum sanctum L. Lamiaceae (Tulasi) & Leaves & $\begin{array}{l}\text { Tuberculosis, ringworm, ear infections, common cold, } \\
\text { cough, bronchitis, general stress syndrome, skin } \\
\text { infections, indigestion, nausea and sinus infection. }\end{array}$ \\
\hline $\begin{array}{l}\text { Oroxylum indicum Vent. Bignoniaceae } \\
\text { (Shyonaka) }\end{array}$ & $\begin{array}{l}\text { Root bark } \\
\text { powder }\end{array}$ & $\begin{array}{l}\text { Digestive aid, arthritic conditions, anti-diarrhoea, and } \\
\text { purgative. }\end{array}$ \\
\hline Operculina turpethum S. Manso (Trivrit) & Root & Constipation and colic obesity. \\
\hline $\begin{array}{l}\text { Phyllanthus amarus L. Euphorbiaceae } \\
\text { (Bhumi amalaki) }\end{array}$ & Whole plant & $\begin{array}{l}\text { Chronic liver disorders, jaundice, viral hepatitis, } \\
\text { dyspepsia, anorexia moderate constipation, chronic colitis, } \\
\text { irritable bowel syndrome, urinary tract infection. }\end{array}$ \\
\hline $\begin{array}{l}\text { Plumbago zeylanica L. Plumbaginaceae } \\
\text { (Chitraka) }\end{array}$ & Root & $\begin{array}{l}\text { Skin conditions, arthritic pain, abortifacient, blood } \\
\text { purifier, obesity and hemorrhoids. }\end{array}$ \\
\hline Ricinus communis L. (Euphorbiaceae) & Seed & $\begin{array}{l}\text { Dysentery, cough, constipation, piles, antivenom to } \\
\text { scorpion stings, rheumatis and nerve disorder }\end{array}$ \\
\hline $\begin{array}{l}\text { Rauwolfia serpentina Benth. Apocynaceae } \\
\text { (Sarpagandha) }\end{array}$ & Root & $\begin{array}{l}\text { High blood pressure, mental agitation, insomnia, sedative, } \\
\text { hypnotic. Sarpagandha is the source of reserpine, an anti- } \\
\text { hypertensive drug used since } 1970 .\end{array}$ \\
\hline Saraca indica L. Caesalpiniaceae (Asoka), & Bark & $\begin{array}{l}\text { Menorrhagia, depression, bleeding, hemorrhoids, uterine } \\
\text { fibroids, considered as a uterine sedative and tonic. }\end{array}$ \\
\hline
\end{tabular}




\section{Bioinformation}

\section{www.bioinformation.net}

\section{Current Trends}

Sida cordifolia L. Malvaceae (Bala)

Solanum surattense Burm.f. Solanaceae

(Kantakari)

Terminalia bellerica DC. (W \& A)

Combretaceae (Bibhitaka)

Tylophora asthmatica W \& A

Asclepiadaceae (Nanjaruppan)

Wedelia calendula (L.) Less. Vitaceae

Withania somnifera Dunal. Solanaceae (Amukkura kizhangu)
Root

Whole plant

Fruits

Root

Leaf and root

Tuber and root
Generalized weakness, post-partum weakness, mental exhaustion, nervousness, bronchospasm and cough. Asthma, cough, bronchspasm, sore throat, constipation, an effective expectorant and diuretic.

General tonic and strengthener, cough, sore throat, fatigue, all types of gastrointestinal disorders and mild laxative. Dry leaf is used to given asthma, tuberculosis and dry cough.

Used as hepatic disorders, stomach and lung cancer

Used for rheumatism and arthritis.

Table 1: Therapeutic uses of medicinal and aromatic plants and their parts used in indigenous systems of Indian medicines. *(Reference for the all the plants cited in table 1, Subhose and colleagues, 2005) 


\begin{tabular}{|c|c|c|}
\hline Botanical name & Chemical composition & Therapeutic uses \\
\hline Adhatoda vasica Nees & $\begin{array}{l}1.0 \% \text { Vasicine } \\
2.0 \% \text { Total alkaloids }\end{array}$ & $\begin{array}{l}\text { Anti-asthmatic, Bronchodilator } \\
\text { Cold remedy }\end{array}$ \\
\hline Andrographis paniculata Wallich ex Nees & $10 \%$ Andrographolides & Hepatoprotectant \\
\hline Boswellia serrata Roxb. & $\begin{array}{l}65 \% \text { Organic acids } \\
20-25 \% \text { Boswellic acid }\end{array}$ & $\begin{array}{l}\text { Antiarthritic, } \\
\text { Antiinflammatory }\end{array}$ \\
\hline Boswellia serrata Roxb. & $\begin{array}{l}75 \% \text { Organic acids, } 40 \% \\
\text { Boswellic acid, } 20 \% \text { Sennosides }\end{array}$ & $\begin{array}{l}\text { Antiarthritic, } \\
\text { Antiinflammatory and laxative action }\end{array}$ \\
\hline Bacopa monniera (L.) Pennell. & $20 \%$ Bacosides A\&B & Memory enhancer \\
\hline Capsicum annum L. & $\begin{array}{l}\text { 40\% Capsaicin, } 75 \% \text { Capsaicin } \\
90 \% \text { Capsaicin }\end{array}$ & Pain reliever \\
\hline Centella asiatica Urb. & $8 \%$ Total triterpenes & Skin, health weight management \\
\hline Coleus forskohlii Briq. Syn & $1 \%$ Forskohlin & Antihypertensive, weight management \\
\hline Curcuma longa L. & $\begin{array}{l}\text { Curcumin C3, } \\
95 \% \text { Curcuminoids }\end{array}$ & $\begin{array}{l}\text { Antioxidant, anti-viral, anti- } \\
\text { inflammatory, } \\
\text { anticarcinogenic }\end{array}$ \\
\hline Emblica officinalis Gaertn. & $30 \%$ Tannins & $\begin{array}{l}\text { Detoxification } \\
\text { Rejuvenating agent }\end{array}$ \\
\hline Garcinia cambogia Desr. & $50 \%(-) \mathrm{HCA}(\mathrm{Ca})$ & Weight management \\
\hline Garcinia indica Chois. & $\begin{array}{l}\text { CitrinÒ crystalline powder } \\
10 \%(-) \text { HCA }\end{array}$ & $\begin{array}{l}\text { Beverages, naturally } \\
\text { Red in color }\end{array}$ \\
\hline Gymnema sylvestre R. Br. & $\begin{array}{l}\text { Gymnema Sylvestre GS } 425 \% \\
75 \% \text { Gymnemic acids }\end{array}$ & Antidiabetic \\
\hline Glycyrrhiza glabra L. & $\begin{array}{l}20 \% \text { Glycyrrhizinic acid } \\
5 \% \text { Lutein }\end{array}$ & $\begin{array}{l}\text { Eyesight-age related } \\
\text { Macular degeneration }\end{array}$ \\
\hline Camellia sinensis (L.) Kuntze & $\begin{array}{l}40 \% \text { Catechins; } 75 \% \text { Catechins } \\
2 \% \text { Caffeine }\end{array}$ & Antioxidant \\
\hline Commiphora mukul Engl. & $\begin{array}{l}\text { Gugulipid } \\
2.5 \% \text { Guggulsterones Z\&E }\end{array}$ & $\begin{array}{l}\text { Cholesterol } \\
\text { Management }\end{array}$ \\
\hline Momordica charantia L. & $\begin{array}{l}\text { 7\% Bitter principles } \\
0.5 \% \text { Charantin }\end{array}$ & Antidiabetic \\
\hline Morinda citrifolia L. & Fruit Powder & General tonic \\
\hline Mucuna pruriens Baker & $\begin{array}{l}\text { 10\% \& 15\% L-Dopa } \\
\text { Min. 20\% Catecholamines }\end{array}$ & $\begin{array}{l}\text { Nerve tonic } \\
\text { Energy }\end{array}$ \\
\hline Melia azadirachta L. & 3\% Bitter Principles & Anti-bacterial \\
\hline Phyllanthus amarus L. & $\begin{array}{l}0.02 \% \text { Phyllanthine \& } \\
\text { Hypophyllanthine }\end{array}$ & Anti-hepatitis \\
\hline Picrorhiza kurroa Royle ex Benth., & $4 \%$ Kutkin & Hepatoprotectant \\
\hline Piper nigrum L. & 95\% Piperine & $\begin{array}{l}\text { Nutrient bio-availability } \\
\text { Enhancer }\end{array}$ \\
\hline Piper longum L. & $1.5 \%$ Piperine & $\begin{array}{l}\text { Biopotentiator, Ant-asthmatic } \\
\text { Thermogenic }\end{array}$ \\
\hline Rubia cordifolia L. & 4:1 Concentration & Skin disorders \\
\hline Sida cordifolia L. & $\begin{array}{l}0.8 \% \text { Ephedrine } \\
10 \% \text { Isoflavones }\end{array}$ & $\begin{array}{l}\text { Bronchodilator } \\
\text { Anti-carcinogenic }\end{array}$ \\
\hline Terminalia arjuna W. \& A. & $1 \%$ Arjunolic acid & Revitalizing, circulation \\
\hline Terminalia bellerica Roxb. & $35 \%$ Tannins & Rejuvenating agent \\
\hline Terminalia chebula Retz. & $30 \%$ Tannins & \\
\hline Tinospora cordifolia Miers & $2.5 \%$ Bitter principles & Diuretic \\
\hline Tribulus terrestris L. & $\begin{array}{l}20 \% \text { Steroidal saponins } \\
45 \% \text { Steroidal saponins }\end{array}$ & $\begin{array}{l}\text { Muscle building, } \\
\text { Anabolic alternative }\end{array}$ \\
\hline Ocimum sanctum L. & $2 \%$ Ursolic acid & $\begin{array}{l}\text { Antidiabetic } \\
\text { Stress management }\end{array}$ \\
\hline Tylophora asthmatica W. \& A. & $0.1 \%$ Total alkaloids & Anti-asthmatic \\
\hline Withania somnifera (L.) Dunal & $\begin{array}{l}.5 \% \text { Withanolides, } 1.0 \% \\
\text { Alkaloids, } 0.25 \% \text { Withaferin }\end{array}$ & Herbal adaptogen \\
\hline Zingiber officinale (Willd.)Rosc. & $5 \%$ Gingerols & $\begin{array}{l}\text { Digestive aid } \\
\text { Ginger soft extract }\end{array}$ \\
\hline
\end{tabular}

Table 2: The pharmacological properties of some Ayurvedic crude drugs support for their therapeutic claims. 


\section{Bioinformation}

by Biomedical Informatics Publishing Group

open access

www.bioinformation.net

Current Trends

\begin{tabular}{lll}
\hline \multicolumn{1}{c}{ Botanical names } & \multicolumn{1}{c}{ Parts used } & Vernacular names \\
\hline Acorus calamus L. ( Araceae) & Rhizome & Vacha \\
Argemone mexicana L. (Papaveraceae) & Fruit & Datura. \\
Curcuma amada L. (Scitaminaceae) & Rhizome & Amba haldi \\
Curcuma longa L. (Scitaminaceae) & Rhizome & Haldi \\
Curcuma aromatica Salish (Scitaminaceae) & Wild turmeric & Jangali haldi \\
Cassia lanceolata L. (Forsk) (Caceslpiniaceae) & Leaves & Thalispathri \\
Glycyrrhiza glabra L. (Papilionaceae) & Root & Jestimadhu \\
Ipomaea hederacea Jacq. (Convolvulaceae) & Pharbitis & Kala dana \\
Withania somnifera Dunal. (Solanaceae) & Vegetable rennet & Aswagandha \\
Myrica nagi Thunb. (Myricaceae) & Leaf & Kaifal \\
Nardostachys jatamansi DC. (Valerianaceae) & Whole plant & Jadamanshi \\
Nigella sativa L. (Ranunculaceae) & Seed & Kalajeera \\
Ptychotis ajowan DC. (Umbelliferae) & Leaf & Ajwain \\
Piper longum L. (Piperaceae) & Fruit & Adamkath \\
Rubia cordifolia L. (Rubiaceae) & Madder root & Medhamahmeda \\
Sapindus trifoliatus L. (Sapindaceae) & Indian fiber & Sonth (dried) \\
Symplocos racemosa Roxb. (Styraceae) & Bark & Majithlall \\
Swertia chirata Ham. (Gentianaceae) & Whole plant & Chiraita \\
Terminalia chebula Retz. (Combretaceae) & Bark and seed & Harda chota \\
Zingiber officinale Roseoe (Gingiferaceae) & Rhizome & Adrak (fresh) \\
\hline
\end{tabular}

Table 3: Medicinal plant parts exported from India. 